\title{
IMPLEMENTASI MANAJEMEN PENDIDIKAN INKLUSIF DI SD NEGERI GADINGAN WATES DAN MI MA'ARIF PAGERHARJO SAMIGALUH
}

\author{
Dian Putera Karana \\ Dinas Pendidikan Kabupaten Kulonprogro \\ pakde.paijo.81@gmail.com
}

\begin{abstract}
Abstrak
Penelitian ini bertujuan untuk mengetahui: (1) keefektifan manajemen pendidikan inklusif (MPI) dilihat dari standar pelayanan minimum, (2) perbedaan MPI di SD negeri dengan MPI di SD swasta, (3) hambatan dalam pelaksanaan MPI, dan (4) solusi dan rekomendasi untuk menyelesaikan hambatan yang terjadi dalam pelaksanaan MPI. Penelitian ini menggunakan pendekatan penelitian evaluasi dengan model discrepancy. Responden penelitian berjumlah 41 orang. Data dikumpulkan menggunakan angket dan dianalisis menggunakan metode analisis deskriptif yang disajikan dalam bentuk angka dan persentase, di mana data yang berwujud angka-angka tersebut selanjutnya diterjemahkan dalam kata-kata atau kalimat. Hasil penelitian sebagai berikut. (1) MPI di SDN Gadingan dilihat dari standar pelayanan minimum termasuk dalam kategori sangat baik dan di MI Ma'arif Pagerharjo termasuk kategori baik. (2) Perbedaan MPI di SDN Gadingan dan MI Ma'arif Pagerharjo terletak pada komponen standar: pendidik dan tenaga kependidikan, sarana dan prasarana, serta pembiayaan. (3) Hambatan: belum adanya pedoman penyelenggaraan pendidikan inklusif, minimnya jadwal guru pembimbing khusus untuk mendampingi guru reguler, minimnya anggaran, terbatasnya sarana dan prasarana. (4) Solusi: menyusun pedoman penyelenggaraan pendidikan inklusif, menambah waktu/jadwal guru pembimbing khusus untuk mendampingi guru reguler, mengusulkan penambahan anggaran dan memenuhi sarana dan prasarana, serta rekomendasinya: pengembangan wawasan dan pengetahuan pendidik dan tenaga kependidikan, optimalisasi pengelolaan sarana dan prasarana, dan pemenuhan kebutuhan anggaran/pembiayaan.
\end{abstract}

Kata kunci: implementasi, manajemen, pendidikan inklusif.

\section{IMPLEMENTATION OF THE INCLUSIVE EDUCATION MANAGEMENT IN SDN GADINGAN WATES AND MI MA'ARIF PAGERHARJO SAMIGALUH}

\author{
Dian Putera Karana \\ Dinas Pendidikan Kabupaten Kulonprogro \\ pakde.paijo.81@gmail.com
}

\begin{abstract}
This study aims to investigate: (1) the effectiveness of the inclusive education management (IEM) in terms of the minimum service standard, (2) the comparison between IEM in public schools and that in private schools, (3) the constraints in the implementation of IEM, and (4) the solutions and recommendations to overcome the constraints in the implementation of IEM. This study used a research approach to the evaluation of the discrepancy model. The respondents consisted of 41 people. The data were collected through a questionnaire, and analyzed by means of the descriptive analysis method using numbers and percentages; the numerical data were then verbally interpreted. The results of the study are as follows. (1) The IEM in SDN Gadingan, the standard of minimum service have been in very good category and the IEM in MI Ma'arif Pagerharjo have been in good category. (2) Differences in the IEM in SDN Gadingan and MI Ma'arif Pagerharjo lies in the standard component of: educators and education personnel, facilities and infrastructure, and financing. (3) The constraints: the unavailability of the guideline for the inclusive education implementation, special guide teachers' minimum time slots to accompany regular teachers, a limited budget, and limited infrastructure and facilities. (4) The solutions: designing a guideline for the inclusive education implementation, adding special guide teachers' time slots to accompany regular teachers, proposing the addition of the budget, and improving the infrastructure and facilities, and recommendations: develop knowledge of educators and education personnel, optimize the management of facilities and infrastructure, and meet the needs of the budget/finance.
\end{abstract}

Keywords: implementation, management, inclusive education. 


\section{Pendahuluan}

Pendidikan merupakan usaha untuk mengembangkan kemampuan seorang individu. Hal ini disampaikan oleh Fattah (2011, p.5) bahwa: "Pendidikan berusaha mengembangkan potensi individu agar mampu berdiri sendiri. Untuk itu individu perlu diberi berbagai kemampuan dalam pengembangan berbagai hal, seperti: konsep, prinsip, kreativitas, tanggung jawab dan keterampilan. Dengan kata lain perlu mengalami perkembangan dalam aspek kognitif, afektif dan psikomotor".

Di Indonesia pendidikan diatur dalam suatu peraturan perundang-undangan, yaitu Undang-Undang Nomor 20 Tahun 2003 tentang Sistem Pendidikan Nasional yang menyatakan bahwa: "Pendidikan Nasional berfungsi mengembangkan kemampuan dan membentuk watak serta peradaban bangsa yang bermartabat dalam rangka mencerdaskan kehidupan bangsa, bertujuan untuk mengembangkan potensi peserta didik agar menjadi manusia yang beriman dan bertaqwa kepada Tuhan Yang Maha Esa, berakhlak mulia, sehat, berilmu, cakap, kreatif, mandiri dan menjadi warga negara yang demokratis serta bertanggung jawab".

Tujuan hakiki tersebut hendaknya menjadi motivasi untuk terus berusaha mewujudkan cita-cita pendidikan yang ideal dan bermutu. Dalam mewujudkan cita-cita tersebut perlu adanya kerjasama yang baik dari berbagai pihak (stakeholder) bidang pendidikan terutama pemerintah pusat dan pemerintah daerah yang dalam hal ini pihak yang memegang peranan penting dalam upaya peningkatan mutu pendidikan nasional secara menyeluruh sesuai kondisi dan kebutuhan masyarakat.

Mendasar Rencana Strategis Pembangunan Pendidikan Tahun 2010-2014 di atas, khususnya terkait dengan "pendidikan untuk semua" bahwa pendidikan (khususnya pada jenjang pendidikan dasar) adalah bagian dari hak asasi manusia dan hak setiap warga negara yang usaha pemenuhannya harus direncanakan dan dijalankan dengan baik. Hak untuk mendapatkan pendidikan dasar sebagai pemenuhan hak asasi manusia telah menjadi komitmen global. Oleh karena itu, program "pendidikan untuk semua" diselenggarakan pada jalur pendidikan formal, nonformal, dan informal dengan sistem pendidikan terbuka dan demokratis serta berkesetaraan gender agar dapat menjangkau mereka yang berdomisili di tempat terpencil serta mereka yang mempunyai kendala ekonomi dan sosial.

Paradigma pendidikan seperti di atas menjamin keberpihakan kepada peserta didik yang memiliki hambatan fisik ataupun mental, hambatan ekonomi dan sosial, ataupun kendala geografis, yaitu layanan pendidikan untuk menjangkau mereka yang tidak terjangkau oleh pendidikan formal. Keberpihakan diwujudkan dalam bentuk penyelenggaraan sekolah khusus, pendidikan layanan khusus, ataupun pendidikan nonformal dan informal, pendidikan dengan sistem guru kunjung, pendidikan jarak jauh, dan bentuk pendidikan khusus lain yang sejenis sehingga menjamin terselenggaranya pendidikan yang demokratis, merata, dan berkeadilan serta berkesetaraan gender.

Penyelenggaraan sekolah khusus ataupun pendidikan layanan khusus merupakan langkah mewujudkan pemerataan dan perluasan akses pendidikan. Peran pemerintah sangat dibutuhkan sebagai pelindung terhadap hak-hak anak untuk mendapatkan pendidikan, termasuk layanan khusus. Hal ini dijelaskan dalam UndangUndang Nomor 20 Tahun 2003 tentang Sistem Pendidikan Nasional (khususnya terkait dengan Pendidikan Khusus) yang menyebutkan bahwa: "Pendidikan Khusus merupakan pendidikan untuk peserta didik yang berkelainan atau peserta didik yang memiliki kecerdasan luar biasa yang diselenggarakan secara inklusif atau berupa satuan pendidikan khusus pada tingkat pendidikan dasar dan menengah".

Hal inilah yang memungkinkan terobosan bentuk pelayanan pendidikan bagi anak berkebutuhan khusus berupa penyelenggaraan pendidikan inklusif. Pendidikan inklusif merupakan sebuah konsep atau pendekatan pendidikan yang berupaya menjangkau semua anak tanpa kecuali 
(Tarmansyah, 2007, p.11). Mereka semua memiliki hak dan kesempatan yang sama untuk memperoleh manfaat yang maksimal dari pendidikan. Lebih lanjut dijelaskan dalam Peraturan Menteri Pendidikan Nasional Nomor 70 Tahun 2009 tentang Penyelenggaraan Pendidikan Inklusif bahwa: "Pendidikan inklusif bertujuan memberikan kesempatan yang seluas-luasnya kepada semua peserta didik yang memiliki kelainan fisik, emosional, mental, dan sosial atau memiliki potensi kecerdasan dan/atau bakat istimewa untuk memperoleh pendidikan yang bermutu sesuai dengan kebutuhan dan kemampuannya, serta mewujudkanpenyelenggaraan pendidikan yang menghargai keanekaragaman, dan tidak diskriminatif bagi semua peserta didik".

Di Kabupaten Kulon Progo melalui Dinas Pendidikan sejak tahun 2007 telah menyelenggarakan layanan pendidikan bagi anak berkebutuhan khusus (ABK). Penyelenggaraan pendidikan inklusif tersebut telah berjalan selama 5 (lima) tahun, sehingga dianggap cukup untuk memaparkan permasalahan-permasalahan yang telah terjadi, termasuk peran stakeholder dalam menjalankan tugas melayani anak berkebutuhan khusus (ABK) di sekolah penyelenggara pendidikan inklusif, sehingga mendapatkan prestasi yang dapat dibanggakan seperti anak-anak lainnya.

Penyelenggaraan pendidikan inklusif di Kabupaten Kulon Progo tidak dilalui dengan mudah dan singkat. Hal ini terbukti bahwa selama proses penyelenggaraan tersebut masih terdapat liku-liku permasalahan yang dihadapi, dari kebijakan yang mengatur, peran stakeholder, sistem pengelolaan, hingga laporan, evaluasi dan pengawasannya.

Permasalahan yang pertama, yaitu terkait dengan kebijakan yang mengatur, dimana pada tahun 2007 belum disusun secara riil oleh Pemerintah Daerah. Namun akhirnya pada tahun 2012 muncul kebijakan tentang Penyelenggaraan Pendidikan Inklusif yang tertuang dalam Peraturan Bupati Kulon Progo nomor 57 tahun 2012, sehingga pada aspek ini sudah mulai diatur secara lebih baik.
Permasalahan yang kedua, yaitu terkait dengan peran stakeholder di bidang pendidikan, dimana masih minimnya kemampuan guru, kepala sekolah dan pihak internal sekolah lainnya dalam mendukung terselenggaranya layanan bagi $\mathrm{ABK}$, hal ini disebabkan oleh masih minimnya pelatihan maupun bimbingan kepada mereka pada substansi materi pendidikan inklusif secara khusus. Selain itu, peran orang tua dan masyarakat masih rendah, mengingat konsep pendidikan inklusif yang mereka miliki masih belum utuh, sesuai maksud dan tujuannya. Contoh dapat dibuktikan dimana persepsi orang tua terhadap layanan ABK masih harus dipisahkan, mengingat $A B K$ akan mengganggu kenyamanan bagi anak-anak mereka yang yang berkategori normal, ABK dianggap mengganggu konsentrasi belajar sehingga anak-anak mereka tidak maksimal dalam mewujudkan prestasi, hal ini jelas membuktikan masih adanya diskriminasi terhadap pelayanan pendidikan. Selain itu, masyarakat masih terpola pada pendidikan yang diselenggarakan di Sekolah Luar Biasa (SLB), dimana $\mathrm{ABK}$ harus sekolah di SLB, tidak bergabung di sekolah reguler, karena dianggap SLB tempat yang tepat untuk ABK, jelas hal ini sama artinya pada diskriminasi pada pelayanan pendidikan di atas.

Permasalahan yang ketiga, yaitu terkait dengan sistem pengelolaan pendidikan, dimana masih minimnya pengetahuan dan ketrampilan dalam pengembangan sekolah reguler menjadi sekolah inklusif. Pengelolaan itu termasuk melakukan modifikasi kurikulum, identifikasi karakteristik peserta didik, pengelolaan sarana dan prasarana, maupun pengelolaan pembiayaan yang berbasis pada layanan pendidikan inklusif. Hal ini disebabkan belum adanya petunjuk/pedoman teknis tentang penyelenggaraan pendidikan inklusif.

Permasalahan yang keempat, yaitu terkait dengan laporan, evaluasi dan pengawasan penyelenggaraan pendidikan inklusif yang masih minim dan belum dapat dilakukan secara rutin dan terpadu. Laporan dapat diwujudkan berupa informasi pelaksanaan dalam kurun waktu tertentu, 
sudah sejaumana dan hal-hal apa yang belum dapat dicapai, sedangkan evaluasi adalah proses menilai sejauhmana ketercapaian program pendidikan inklusif, serta pengawasan adalah sistem pengendalian yang dilakukan, sehingga penyelenggaraan pendidikan inklusif dilaksanakan sesuai maksud dan tujuannya, termasuk menghimpun permasalahan-permasalahan yang dihadapi di atas sehingga dapat menyusun rekomendasi penyelesaiannya.

Berdasarkan permasalahan yang dipaparkan tersebut, maka perlu adanya informasi tentang Implementasi Manajemen Pendidikan Inklusif Jenjang SD/MI di Kabupaten Kulon Progo, yakni dengan melakukan penelitian. Penelitian tersebut didesain dengan pendekatan kualitatif deskriptif dan menggunakan model evaluasi discrepancy, yaitu mencari ketimpangan atau kesenjangan implementasi manajemen pendidikan inklusif yang ada dengan yang riil dilakukan dengan standar pelayanan minimum. Selain itu, rencana penelitian ini juga bertujuan melihat sejauhmana perbedaan implementasi manajemen pendidikan inklusif di sekolah negeri dengan sekolah swasta, sehingga bagi peneliti yang sehari-hari bertugas sebagai staf di Bidang Pendidikan Dasar Dinas Pendidikan Kabupaten Kulon Progo dapat mengoptimalkan manfaat serta hasilnya dalam menjalankan tugas pokok dan fungsinya.

Konsep pendidikan inklusif diutarakan oleh Ilahi (2013, p.24) bahwa: "konsep pendidikan inklusif merupakan konsep pendidikan yang mempresentasikan keseluruhan aspek yang berkaitan dengan keterbukaan dalam menerima anak berkebutuhan khusus untuk memperoleh hak dasar mereka sebagai warga negara. Pendidikan inklusif didefinisikan sebagai sebuah konsep yang menampung semua anak yang berkebutuhan khusus ataupun anak yang memiliki kesulitan membaca dan menulis".

Hornby (2012, p.3) mengemukakan bahwa "inclusive education as meaning increasing the numbers of children with SEN in mainstream schools, while maintaining special schools for those who need them". Pengertian di atas memiliki arti bahwa pendidikan inklusif sebagai upaya meningkatkan jumlah anak-anak dengan SEN di sekolah umum, dengan tetap menjaga sekolah khusus bagi mereka yang membutuhkannya. Hal ini dimaksudkan bahwa dengan adanya sekolah inklusi maka tidak menutup kemungkinan adanya kebutuhan sekolah khusus (Sekolah Luar Biasa) sebagai sarana konsultasi dan koordinasi terkait masalah teknis pelayanan anak.

Pendidikan inklusif sering dikaitkan dengan berbagai penafsiran, Tim ASB (2011, pp.2-4) memaparkan kasus yang terjadi sebagai berikut: "Kasus 1: Sekolah hanya terbuka pada satu jenis disabilitas saja, misalnya untuk anak penyandang tunanetra dan tunarungu saja. Praktik keterbukaan semacam ini merupakan indikasi pendidikan integrasi. Kasus 2: Sekolah menerima anak berkebutuhan khusus dan anak tersebut harus mengikuti proses pembelajaran dengan bahan pembelajaran yang sama tanpa penyesuaian, tanpa alat bantu, dan juga harus mengikuti kurikulum reguler yang tidak sesuai dengan kebutuhan dan kecepatan anak dalam belajar. Hal ini juga merupakan indikasi pendidikan integrasi. Kasus 3: Sekolah menerima semua anak termasuk anak berkebutuhan khusus dengan latar belakang disabilitas yang beragam. Sekolah dan guru melakukan penyesuaian kurikulum dan proses pembelajaran untuk mengakomodasi kemampuan dan kebutuhan anak yang berbeda-beda. Guru mengedepankan kegiatan pembelajaran bagi semua anak secara bersama-sama dan memberikan waktu luang untuk jam belajar tambahan bagi anak yang membutuhkan perbaikan atau remidi. Situasi pembelajaran seperti ini terjadi dalam sekolah penyelenggara pendidikan inklusif".

Suyanto \& Mudjito (2012, p.10) mengatakan terdapat 3 model pendidikan bagi anak berkebutuhan khusus, yakni: mainstream, integratif dan inklusi. Secara rinci sebagai berikut: "Mainstream adalah system pendidikan yang menempatkan anak-anak berkebutuhan khusus di sekolah-sekolah umum, mengikuti kurikulum akademis yang berlaku dan guru yang ada tidak 
harus melakukan adaptasi kurikulum. Mainstream biasanya dilakukan pada anakanak yang sakit, tetapi sakitnya tidak berdampak pada kemampuan kognitif, seperti epilepsy, asma dan anak-anak kecacatan sensori. Ini bias diatasi dengan fasilitas peralatan, seperti alat bantu dan buku Braille. Model Integratif adalah menempatkan siswa yang berkebutuhan khusus dalam kelas anak-anak normal, dimana anak-anak berkebutuhan khusus hanya mengikuti pelajaran-pelajaran yang dapat mereka ikuti dari gurunya. Sedangkan untuk mata pelajaran akademisnya, anak-anak berkebutuhan khusus itu menerima pelajaran khusus di kelas yang berbeda, dan terpisah dengan teman-teman mereka. Penempatan integrasi tidak sama dengan integrasi pengajaran dan integrasi social, karena integrasi tergantung pada dukungan yang diberikan sekolah. Model ketiga, yakni inklusif. Menurut Permendiknas No. 70 tahun 2009, dalam model ini semua peserta didik yang memiliki kelainan dan potensi kecerdasan dan atau bakat istimewa untuk mengikuti pendidikan dan pembelajaran di sekolah regular, atau umum. Tujuannya, untuk memberikan kesempatan yang seluas-luasnya dan mewujudkan penyelenggaraan pendidikan yang menghargai keanekaragaman dan tidak diskriminatif".

Minister of National Education Republic of Indonesia (2010, p.108) menyatakan masih terdapat hambatan dalam pelaksanaan pendidikan inklusif, hal ini tertuang sebagai berikut: "Many children with special needs are not yet served for various reason, such as: (1) the unreachabel location of the school for the children with special needs, (2) the unreadiness of regular school to accept the children with special needs, (3) the low awareness of parent to put the children to school for the handicap possessed by their children, (4) the lack of information on education for the children with special needs".

Kutipan tersebut memiliki arti bahwa masih banyak anak berkebutuhan khusus yang belum mendapat layanan pendidikan karena sejumlah alasan, antara lain: (1) lokasi SLB yang sulit dijangkau, (2) sekolah umum belum siap menerima anak berke- butuhan khusus, (3) rendahnya perhatian orang tua untuk menyekolahkan anaknya karen malu kecacatan anaknya, (4) kurangnya informasi tentang pendidikan bagi anak berkebutuhan khusus.

Atta, Shah \& Khan (2005, pp.1-2) mengemukakan pengertian sekolah inklusi sebagai berikut: "Inclusive school is a school where all children are taught to understand and appreciate human differences. Teachers and administrators receive the support necessary to include all students in regular education classrooms".

Pengertian tersebut memiliki arti bahwa sekolah inklusif adalah sekolah di mana semua anak-anak diajarkan untuk memahami dan menghargai perbedaan manusia. Guru dan administrator menerima dukungan yang diperlukan untuk memasukkan semua siswa di kelas pendidikan reguler.

Standar Pelayanan Minimum yang selanjutnya disingkat SPM adalah ketentuan tentang jenis dan mutu pelayanan dasar yang merupakan urusan wajib daerah yang berhak diperoleh setiap warga secara minimal. Lebih lanjut, pelayanan dasar adalah jenis pelayanan publik yang mendasar dan mutlak untuk memenuhi kebutuhan masyarakat dalam kehidupan sosial, ekonomi dan pemerintahan.

Dalam dunia pendidikan, standar pelayanan minimum lebih dikenal dalam kerangka Standar Nasional Pendidikan. Tilaar (2006, pp.169-170) mengemukakan terdapat 8 Standar Nasional Pendidikan, antara lain: (1) standar isi yang merupakan materi dari tingkat kompetensi yang harus dikuasai oleh setiap peserta didik di dalam berjenis tingkat dan jenis pendidikan; (2) standar proses meliputi pelaksanaan pembelajaran pada satuan pendidikan untuk mencapai standar kompetensi lulusan; (3) standar kompetensi lulusan merupakan kualifikasi kemampuan lulusan yang berkaitan dengan sikap, pengetahuan dan keterampilan; (4) standar pendidik dan tenaga kependidikan merupakan standar nasional tentang kriteria pendidikan prajabatan dan kelayakan fisik maupun mental serta pendidikan dalam jabatan dari tenaga guru serta tenaga kependidikan lainnya; 
standar sarana dan prasarana mengenai kriteria minimal tentang ruang belajar, perpustakaan, tempat olahraga, tempat ibadah, tempat bermain dan rekreasi, laboratorium, bengkel kerja, sumber belajar lainnya yang diperlukanuntuk menunjang proses pembelajaran; (6) standar pengelolaan meliputi perencanaan pendidikan, pelaksanaan dan pengawasan kegiatan pendidikan pada tingkat satuan pendidikan, pengelolaan pendidikan di tingkat kabupaten/kota, provinsi dan nasional; (7) standar pembiayaan merupakan standar nasional yang berkaitan dengan komponen dan besarnya biaya operasi satuan pendidikan selama satu tahun; (8) standar penilaian pendidikan merupakan standar nasional penilaian pendidikan tentang mekanisme, prosedur, instrumen penilaian hasil belajar peserta didik.

Secara rinci dijelaskan kriteria standar pelayanan minimum untuk sekolah inklusi yang mengacu pada 8 Standar Nasional Pendidikan dikutip dari Panduan 1: Kriteria Standar Pelayanan Minimum Sekolah Inklusi (Tim ASB, 2011, pp.30-31) antara lain: (1) standar isi, terdiri dari: identifikasi dan assesmen, adaptasi dan modifikasi kurikulum, dan rencana pembelajaran individual (RPI); (2) standar proses, terdiri dari: strategi pembelajaran, dan setting kelas; (3) standar kompetensi lulusan, terdiri dari: standar kompetensi lulusan bagi anak berkebutuhan khusus, program pengembangan ketrampilan hidup (Life Skill), dan ujian sekolah dan surat tanda tamat belajar (STTB); (4) standar kompetensi Pendidik dan Tenaga Kependidikan, terdiri dari: peningkatan kualitas pendidikan dan tenaga kependidikan, peran guru pembimbing khusus (GPK), dan praktik dan strategi pembelajaran bagi anak berkebutuhan khusus; (5) standar sarana dan prasarana, terdiri dari: aksesibilitas fisik, dan materi pembelajaran; (6) standar pengelolaan, terdiri dari: kebijakan dan struktur, sikap dan penggunaan itilah yang tepat dan bermartabat, serta jejaring sekolah dengan orang tua, masyarakat dan pihak terkait lainnya; (7) standar pembiayaan; (8) standar penilaian, terdiri dari: strategi pe- ngembangan penilaian hasil belajar anak berkebutuhan khusus, dan portofolio siswa.

Arikunto $(2013$, p.3) menjelaskan bahwa evaluasi pendidikan berasal dari dua kata yaitu "mengukur dan menilai". Secara detil sebagai berikut: "Mengukur adalah membandingkan sesuatu dengan satu ukuran. Pengukuran bersifat kuantitatif. Menilai adalah mengambil suatu keputusan terhadap sesuatu dengan ukuran baik buruk. Penilaian bersifat kualitatif. Mengadakan evaluasi meliputi kedua langkah di atas, yakni mengukur dan menilai. Meskipun kini memiliki makna yang lebih luas, namun pada awalnya pengertian evaluasi pendidikan selalu dikaitkan dengan prestasi belajar siswa. Definisi yang pertama dikembangkan oleh Ralph Tyler. Ahli ini mengatakan bahwa evaluasi merupakan sebuah proses pengumpulan data untuk menentukan sejauh mana, dalam hal apa, bagian mana tujuan pendidikan sudah tercapai. Jika belum, bagaimana yang belum dan apa sebabnya. Definisi yang lebih luas dikemukakan oleh dua orang ahli lain, yakni Cronbach dan Stufflebeam. Tambahan definisi tersebut adalah bahwa proses evaluasi bukan sekedar mengukur sejauh mana tujuan tercapai, tetapi digunakan untuk membuat keputusan".

Pengertian evaluasi yang dikutip dari Wirawan (2011, p.7) memiliki arti yang hampir sama, antara lain: "Riset evaluasi atau evaluasi sebagai riset untuk mengumpulkan, menganalisis, dan menyajikan informasi yang bermanfaat mengenai objek evaluasi, menilai dengan membandingkannya dengan indikator evaluasi dan hasilnya dipergunakan untuk mengambil keputusan mengenai obyek evaluasi".

Model Evaluasi Ketimpangan menurut Wirawan (2011, pp.80-124) adalah The Discrepancy Evaluation Model yang dikembangkan oleh Malcolm M. Provus (1971) bahwa evaluasi merupakan suatu seni (art) melukiskan ketimpangan antara standar kinerja dengan kinerja yang terjadi. 


\section{Metode Penelitian}

Penelitian ini merupakan penelitian evaluasi, dengan model discrepancy (kesenjangan/ketimpangan). Penelitian evaluasi bertujuan untuk menentukan nilai dan kegunaan bagi masyarakat. Sehubungan itu, penelitian ini disusun untuk mengetahui kegunaan/kebermanfaatan implementasi manajemen pendidikan inklusif di sekolah/madrasah.

Penelitian ini dilaksanakan pada bulan Juli 2013 hingga bulan September 2013 di Wilayah Kabupaten Kulon Progo, secara detil ada di 2 (dua) sekolah, yaitu: SD Negeri Gadingan Kecamatan Wates (sebagai sekolah berstatus negeri) dan MI Ma'arif Pagerharjo Kecamatan Samigaluh (sebagai sekolah berstatus swasta).

Unit analisis penelitian ini adalah seluruh responden penelitian yang terdapat di 2 (dua) sekolah, yaitu: SD Negeri Gadingan Kecamatan Wates (sebagai sekolah berstatus negeri) dan MI Ma'arif Pagerharjo Kecamatan Samigaluh (sebagai sekolah berstatus swasta), yang secara keseluruhan terdapat 2 orang kepala sekolah, 22 orang guru, 9 orang pengurus komite sekolah. Selain itu, terdapat orang tua/wali dari anak berkebutuhan khusus (ABK) yang keseluruhan sejumlah 8 orang. Maka keseluruhan unit analisis penelitian ini adalah 41 orang.

Metode pengumpulan data menggunakan angket. Metode angket tersebut berupa angket tertutup guna mengukur persepsi atau sikap seseorang. Selain itu, penelitian ini bertujuan untuk mengetahui gambaran persepsi responden penelitian menggunakan angket terbuka.

Uji validitas yang digunakan dalam penelitian ini adalah pengujian validitas isi. Dalam menguji validitas isi tersebut menggunakan validitas logis dengan mengkonsultasikan butir instrumen kepada ahlinya. Untuk menguji validitas konstrak penelitian ini dilakukan oleh seorang Doktor bidang Administrasi Pendidikan. Uji Validitas empiris penelitian ini dilakukan dengan menguji coba instrumen kepada beberapa responden penelitian, yaitu diujikan ke semua responden penelitian di SDN
1 Giripurwo Kecamatan Girimulyo dan di MI Muhammadiyah Grubug Kecamatan Nanggulan sebanyak 42 responden penelitian. Adapun teknik yang digunakan untuk melakukan uji validitas empiris menggunakan Rumus Korelasi Product Moment. Pengujian reliabilitas instrumen pada penelitian menggunakan metode internal, yaitu menguji butir-butir jawaban dengan rumus Spearman Brown.

Analisis data merupakan aktivitas ketika data sudah terkumpul. Analisis data penelitian ini menggunakan metode analisis deskriptif yang dapat disajikan dalam bentuk angka dan persentase, dimana data yang berwujud angka-angka tersebut selanjutnya diterjemahkan dalam kata-kata atau kalimat.

Data yang dikumpulkan dianalisis dengan langkah-langkah berikut: Pertama, melakukan skoring. Data yang diperoleh dari instrumen yang telah diambil dari responden penelitian berupa jawaban Ya dan Tidak. Selanjutnya memberikan skor, yaitu untuk "Ya" dengan angka 1 dan "Tidak" dengan angka 0 .

Langkah kedua adalah melakukan tabulasi. Data yang telah diberi skor, selanjutnya disusun dalam bentuk persentase, yaitu dengan rumus, sebagai berikut:

$$
\%=\mathrm{F} / \mathrm{N} \text { X } 100
$$

Keterangan:

$\mathrm{F}=$ jumlah perolehan skor yang ada

$\mathrm{N}=$ jumlah skor maksimal sesuai standar

Langkah ketiga adalah melakukan konversi skor menjadi nilai. Data yang telah diberi skor, selanjutnya diolah untuk dikonversi menjadi nilai dengan rentangan skala 5 seperti disajikan pada Tabel 5 .

Tabel 1. Konversi Skor Ideal menjadi Nilai Skala 5

\begin{tabular}{ccc}
\hline Nilai & Skor & Kategori \\
\hline $\mathrm{A}$ & $\overline{\mathrm{X}}+1,80 . \mathrm{SB}_{\mathrm{i}}<\mathrm{X}$ & Sangat Baik \\
\hline $\mathrm{B}$ & $\overline{\mathrm{X}}+0,60 . \mathrm{SB}_{\mathrm{i}}<\mathrm{X} \leq \overline{\mathrm{X}}+1,80 . \mathrm{SB}_{\mathrm{i}}$ & Baik \\
\hline $\mathrm{C}$ & $\overline{\mathrm{X}}-0,60 . \mathrm{SB}_{\mathrm{i}}<\mathrm{X} \leq \overline{\mathrm{X}}+0,60 . \mathrm{SB}_{\mathrm{i}}$ & Cukup \\
\hline $\mathrm{D}$ & $\overline{\mathrm{X}}-1,80 . \mathrm{SB}_{\mathrm{i}}<\mathrm{X} \leq \overline{\mathrm{X}}-0,60 . \mathrm{SB}_{\mathrm{i}}$ & Kurang \\
\hline $\mathrm{E}$ & $\mathrm{X} \leq \overline{\mathrm{X}}-1,80 . \mathrm{SB}_{\mathrm{i}}$ & Sangat Kurang \\
\hline
\end{tabular}

Sumber: Sukardjo \& Sari (2009, p.84) 
Pertama-tama dicari rerata ideal $(\overline{\mathrm{X}})$ dan simpangan baku ideal $\left(\mathrm{SB}_{\mathrm{i}}\right)$. Rerata ideal $=1 / 2$ (skor maksimal ideal + skor minimal ideal). Dan besarnya simpangan baku ideal $=1 / 6$ (skor maksimal ideal - skor minimal ideal). Selanjutnya, setelah data dapat ditabulasi dalam persentase dengan rumus seperti di atas, maka analisis data dilanjutkan untuk mendeskripsikan ke dalam kalimat atau kata-kata.

\section{Hasil Penelitian dan Pembahasan}

Pelaksanaan konsep manajemen pendidikan inklusif di SD Negeri Gadingan Kecamatan Wates sangat variatif, hal ini dilihat dari hasil pengambilan data yang didapat. Selanjutnya data tersebut diolah menggunakan Tabel Konversi Skor menjadi Kategori, yang terdiri beberapa kategori, antara lain: Sangat Baik, Baik, Cukup, Kurang dan Sangat Kurang.

Tabel 2. Hasil Konversi Skor Ideal Menjadi Nilai Skala 5 Di SDN Gadingan Kecamatan Wates

\begin{tabular}{|c|c|c|}
\hline No & Indikator SPM & Total Skor \\
\hline 1 & Standar Isi & $\begin{array}{c}138 \\
\text { (Sangat Baik) }\end{array}$ \\
\hline 2 & Standar Proses & $\begin{array}{c}224 \\
\text { (Sangat Baik) }\end{array}$ \\
\hline 3 & Standar Kompetensi Lulusan & $\begin{array}{c}52 \\
\text { (Sangat Baik) }\end{array}$ \\
\hline 4 & $\begin{array}{l}\text { Standar Pendidik dan Tenaga } \\
\text { Kependidikan }\end{array}$ & $\begin{array}{c}101 \\
\text { (Sangat Baik) }\end{array}$ \\
\hline 5 & Standar Sarana dan Prasarana & $\begin{array}{c}43 \\
\text { (Baik) }\end{array}$ \\
\hline 6 & Standar Pengelolaan & $\begin{array}{c}260 \\
\text { (Baik) }\end{array}$ \\
\hline 7 & Standar Pembiayaan & $\begin{array}{c}60 \\
\text { (Sangat Baik) }\end{array}$ \\
\hline 8 & Standar Penilaian Pendidikan & $\begin{array}{c}124 \\
\text { (Sangat Baik) }\end{array}$ \\
\hline
\end{tabular}

Berdasarkan hasil yang didapat khususnya pada indikator standar isi, total skor yang didapat 138 poin, dengan skor maksimal sebesar 147, maka persentase indikator standar isi secara keseluruhan adalah 93,88\% yang memiliki kategori "sangat baik". Hal ini berarti pencapaian indikator terkait identifikasi dan assesmen, adaptasi dan modifikasi kurikulum, rencana pembelajaran individual (RPI) bagi anak berkebutuhan khusus dikategorikan "sangat baik".

Sekolah ini berarti telah melaksanakan secara "sangat baik" dalam identifikasi dan assesmen anak berkebutuhan khusus, baik peserta didik baru, maupun yang sudah menempuh proses belajar mengajar lebih dari 1 tahun. Selain itu, sekolah ini juga telah berusaha untuk melakukan adaptasi dan modifikasi kurikulum dengan "sangat baik", termasuk dalam penyusunan rencana pembelajaran individual (RPI).

Berdasarkan hasil yang didapat khususnya pada indikator standar proses, maka total nilai yang didapat sebesar 224 poin, dengan skor maksimal sebesar 231, maka persentase indikator standar proses secara keseluruhan adalah $96,97 \%$ yang memiliki kategori "sangat baik". Hal ini berarti pencapaian indikator terkait strategi pembelajaran dan setting kelas bagi anak berkebutuhan khusus dikategorikan "sangat baik".

Sekolah ini berarti telah melaksanakan secara "sangat baik" dalam melaksanakan pembelajaran, termasuk penataan/ setting kelas, tentunya dengan strategi yang tepat sesuai dengan kebutuhan peserta didik. Strategi pembelajaran lebih variatif dan tidak monoton, termasuk pengaturan kelas yang mendukung pada materi pembelajaran yang disampaikan.

Berdasarkan hasil yang didapat khususnya pada indikator standar kompetensi lulusan (SKL), maka total skor yang didapat sebesar 52 poin, dengan skor maksimal sebesar 63 poin, maka persentase indikator SKL secara keseluruhan adalah 82,54\% yang memiliki kategori "sangat baik". Hal ini berarti pencapaian indikator terkait standar kompetensi lulusan bagi anak berkebutuhan khusus, program pengembangan ketrampilan hidup (life skill), ujian sekolah dan surat tanda tamat belajar (STTB) bagi anak berkebutuhan khusus dikategorikan "sangat baik".

Sekolah ini berarti telah melaksanakan secara "sangat baik" dalam proses penentuan standar kompetensi lulusan, termasuk dalam pengembangan ketrampilan 
hidup, pengelolaan ujian sekolah dan surat tanda tamat belajar bagi anak berkebutuhan khusus.

Berdasarkan hasil yang didapat khususnya pada indikator standar pendidik dan tenaga kependidikan, maka total skor yang didapat sebesar 101 poin, dengan skor maksimal sebesar 105 poin, maka persentase indikator standar pendidik dan tenaga kependidikan secara keseluruhan adalah 96,19\% yang memiliki kategori "sangat baik". Hal ini berarti pencapaian indikator terkait peningkatan kualitas pendidikan dan tenaga kependidikan, peran guru pembimbing khusus (GPK), praktik dan strategi pembelajaran bagi anak berkebutuhan khusus dikategorikan "sangat baik".

Sekolah ini berarti telah melaksanakan secara "sangat baik" dalam pembinaan bagi pendidik dan tenaga kependidikan, termasuk mengoptimalkan peran guru pembimbing khusus (GPK). Praktik dan strategi pembelajaran yang diberikan untuk anak berkebutuhan khusus pun tepat sesuai karakteristik dan kebutuhan peserta didik.

Berdasarkan hasil yang didapat khususnya pada indikator standar sarana dan prasarana, maka total skor yang didapat sebesar 43 poin, dengan skor maksimal sebesar 63, maka persentase indikator standar sarana dan prasarana secara keseluruhan adalah $68,25 \%$ yang memiliki kategori "baik". Hal ini berarti pencapaian indikator terkait aksesibilitas fisik dan materi pembelajaran bagi anak berkebutuhan khusus dikategorikan "baik".

Sekolah ini berarti telah melaksanakan secara "baik" dalam hal pemenuhan aksesibilitas fisik, atau prasarana yang mendukung bagi anak berkebutuhan khusus. Sarana dan prasarana tersebut tentunya sesuai dengan kebutuhan dan karakter peserta didik.

Berdasarkan hasil yang didapat khususnya pada indikator standar pengelolaan, maka total skor yang didapat sebesar 260 poin, dengan skor maksimal sebesar 336, maka persentase indikator standar pengelolaan secara keseluruhan adalah $77,38 \%$ yang memiliki kategori "baik". Hal ini berarti pencapaian indikator terkait kebijakan dan struktur, sikap dan penggunaan itilah yang tepat dan bermartabat, jejaring sekolah dengan orang tua, masyarakat dan pihak terkait lainnya bagi anak berkebutuhan khusus dikategorikan "baik".

Sekolah ini berarti telah melaksanakan sesuai kebijakan yang telah diterbitkan dengan "baik", termasuk menjalan tugas sesuai fungsi dan jabatan dalam struktur organisasi. Di sekolah ini juga telah menggunakan istilah yang tepat dan bermartabat khusus yang berkenaan dengan pelayanan bagi anak berkebutuhan khusus. Sekolah ini juga telah melaksanakan komunikasi dengan orang, masyarakat dan pihak terkait lainnya, sehingga pelayanan bagi anak berkebutuhan khusus lebih baik dan bermutu.

Berdasarkan hasil yang didapat khususnya pada standar pembiayaan, maka total skor yang didapat sebesar 60 poin, dengan skor maksimal sebesar 63, maka persentase indikator standar pembiayaan secara keseluruhan adalah 95,24\% yang memiliki kategori "sangat baik". Hal ini berarti pencapaian indikator terkait standar pembiayaan sekolah inklusi dikategorikan "sangat baik".

Sekolah ini berarti telah mengelola dengan "sangat baik" pembiayaan secara efektif dan efisien, tentunya dari proses perencanaan, pelaksanaan hingga pelaporan berjalan sesuai dengan pedoman yang dipersyaratkan.

Berdasarkan hasil yang didapat khususnya pada indikator standar penilaian pendidikan, maka total skor yang didapat sebesar 124 poin, dengan skor maksimal sebesar 126, maka persentase indikator standar penilaian Pendidikan secara keseluruhan adalah $98,41 \%$ yang memiliki kategori "sangat baik". Hal ini berarti pencapaian indikator terkait strategi pengembangan penilaian hasil belajar dan portofolio siswa bagi anak berkebutuhan khusus dikategorikan "sangat baik".

Sekolah ini berarti telah melaksanakan pengembangan penilaian hasil belajar dan portofolio bagi anak berkebutuhan khusus dengan "sangat baik". 
Tabel 3. Hasil Konversi Skor Ideal Menjadi Nilai Skala 5 Di MI Ma'arif Pagerharjo

\begin{tabular}{|c|c|c|}
\hline No & Indikator SPM & Total Skor \\
\hline 1 & Standar Isi & $\begin{array}{c}115 \\
\text { (Sangat Baik) }\end{array}$ \\
\hline 2 & Standar Proses & $\begin{array}{c}177 \\
\text { (Sangat Baik) }\end{array}$ \\
\hline 3 & $\begin{array}{l}\text { Standar Kompetensi } \\
\text { Lulusan }\end{array}$ & $\begin{array}{c}42 \\
\text { (Baik) }\end{array}$ \\
\hline 4 & $\begin{array}{l}\text { Standar Pendidik dan } \\
\text { Tenaga Kependidikan }\end{array}$ & $\begin{array}{c}59 \\
\text { (Cukup) }\end{array}$ \\
\hline 5 & $\begin{array}{l}\text { Standar Sarana dan } \\
\text { Prasarana }\end{array}$ & $\begin{array}{c}24 \\
\text { (Cukup) }\end{array}$ \\
\hline 6 & Standar Pengelolaan & $\begin{array}{c}273 \\
\text { (Sangat Baik) }\end{array}$ \\
\hline 7 & Standar Pembiayaan & $\begin{array}{c}18 \\
\text { (Kurang) }\end{array}$ \\
\hline 8 & $\begin{array}{l}\text { Standar Penilaian } \\
\text { Pendidikan }\end{array}$ & $\begin{array}{c}104 \\
\text { (Sangat Baik) }\end{array}$ \\
\hline
\end{tabular}

Berdasarkan hasil yang didapat khususnya pada indikator standar isi, maka total skor yang didapat sebesar 115 poin, dengan skor maksimal sebesar 140, maka persentase indikator standar isi secara keseluruhan adalah $82,14 \%$ yang memiliki kategori "sangat baik". Hal ini berarti pencapaian indikator terkait identifikasi dan assesmen, adaptasi dan modifikasi kurikulum, rencana pembelajaran individual (RPI) bagi anak berkebutuhan khusus dikategorikan "sangat baik".

Sekolah ini berarti telah melaksanakan secara "sangat baik" dalam identifikasi dan assesmen anak berkebutuhan khusus, baik peserta didik baru, maupun yang sudah menempuh proses belajar mengajar lebih dari 1 tahun. Selain itu, sekolah ini juga telah berusaha untuk melakukan adaptasi dan modifikasi kurikulum dengan "baik", termasuk dalam penyusunan rencana pembelajaran individual (RPI).

Berdasarkan hasil yang didapat khususnya pada indikator standar proses, maka total skor yang didapat sebesar 177 poin, dengan skor maksimal sebesar 220, maka persentase indikator standar proses secara keseluruhan adalah $80,45 \%$ yang memiliki kategori "sangat baik". Hal ini berarti pencapaian indikator terkait strategi pembelajaran dan setting kelas bagi anak berkebutuhan khusus dikategorikan "sangat baik".

Sekolah ini berarti telah melaksanakan secara "sangat baik" dalam melaksanakan pembelajaran, termasuk penataan/ setting kelas, tentunya dengan strategi yang tepat sesuai dengan kebutuhan peserta didik. Strategi pembelajaran lebih variatif dan tidak monoton, termasuk pengaturan kelas yang mendukung pada materi pembelajaran yang disampaikan.

Berdasarkan hasil yang didapat khususnya pada indikator standar kompetensi lulusan (SKL), maka total skor yang didapat sebesar 42 poin, dengan skor maksimal sebesar 60 poin, maka persentase indikator standar kompetensi lulusan (SKL) secara keseluruhan adalah $70 \%$ yang memiliki kategori "baik". Hal ini berarti pencapaian indikator terkait standar kompetensi lulusan bagi anak berkebutuhan khusus, program pengembangan ketrampilan hidup (life skill), ujian sekolah dan surat tanda tamat belajar (STTB) bagi anak berkebutuhan khusus dikategorikan "baik".

Sekolah ini berarti telah melaksanakan secara "baik" dalam proses penentuan standar kompetensi lulusan, termasuk dalam pengembangan ketrampilan hidup, pengelolaan ujian sekolah dan surat tanda tamat belajar bagi anak berkebutuhan khusus.

Berdasarkan hasil yang didapat khususnya pada indikator standar pendidik dan tenaga kependidikan, maka total skor yang didapat sebesar 59 poin, dengan skor maksimal sebesar 100 poin, maka persentase indikator standar pendidik dan tenaga kependidikan secara keseluruhan adalah 59\% yang memiliki kategori "cukup". Hal ini berarti pencapaian indikator terkait peningkatan kualitas pendidikan dan tenaga kependidikan, peran guru pembimbing khusus (GPK), praktik dan strategi pembelajaran bagi anak berkebutuhan khusus dikategorikan "cukup".

Sekolah ini berarti telah melaksanakan secara "cukup" dalam pembinaan bagi pendidik dan tenaga kependidikan, ter-masuk mengoptimalkan peran guru pembim- 
bing khusus (GPK). Praktik dan strategi pembelajaran yang diberikan untuk anak berkebutuhan khusus pun tepat sesuai karakteristik dan kebutuhan peserta didik.

Berdasarkan hasil yang didapat khususnya pada indikator standar sarana dan prasarana, maka total skor yang didapat sebesar 24 poin, dengan skor maksimal sebesar 60, maka persentase indikator standar sarana dan prasarana secara keseluruhan adalah $40 \%$ yang memiliki kategori "cukup". Hal ini berarti pencapaian indikator terkait aksesibilitas fisik dan materi pembelajaran bagi anak berkebutuhan khusus dikategorikan "cukup".

Sekolah ini berarti telah melaksanakan secara "cukup" dalam hal pemenuhan aksesibilitas fisik, atau prasarana yang mendukung bagi anak berkebutuhan khusus. Sarana dan prasarana tersebut tentunya sesuai dengan kebutuhan dan karakter peserta didik.

Berdasarkan hasil yang didapat khususnya pada indikator standar pengelolaan, maka total skor yang didapat sebesar 273 poin, dengan skor maksimal sebesar 320, maka persentase indikator standar pengelolaan secara keseluruhan adalah $85,31 \%$ yang memiliki kategori "sangat baik". Hal ini berarti pencapaian indikator terkait kebijakan dan struktur, sikap dan penggunaan itilah yang tepat dan ber-martabat, jejaring sekolah dengan orang tua, masyarakat dan pihak terkait lainnya bagi anak berkebutuhan khusus dikategorikan "sangat baik".

Sekolah ini berarti telah melaksanakan sesuai kebijakan yang telah diterbitkan dengan "sangat baik", termasuk menjalan tugas sesuai fungsi dan jabatan dalam struktur organisasi. Di sekolah ini juga telah menggunakan istilah yang tepat dan bermartabat khusus yang berkenaan dengan pelayanan bagi anak berkebutuhan khusus. Sekolah ini juga telah melaksanakan komunikasi dengan orang, masyarakat dan pihak terkait lainnya, sehingga pelayanan bagi anak berkebutuhan khusus lebih baik dan bermutu.

Berdasarkan hasil yang didapat khususnya pada indikator standar pembiaya- an, maka total skor yang didapat sebesar 18 poin, dengan skor maksimal sebesar 60, maka persentase indikator standar pembiayaan secara keseluruhan adalah $30 \%$ yang memiliki kategori "kurang". Hal ini berarti pencapaian indikator terkait standar pembiayaan sekolah inklusi dikategorikan "kurang".

Sekolah ini berarti mengelola pembiayaan dengan "kurang" efektif dan efisien, tentunya dari proses perencanaan, pelaksanaan hingga pelaporan berjalan sesuai dengan pedoman yang dipersyaratkan.

Berdasarkan hasil yang didapat khususnya pada indikator standar penilaian pendidikan, maka total skor yang didapat sebesar 104 poin, dengan skor maksimal sebesar 120, maka persentase indikator Implementasi Manajemen Pendidikan Inklusif dilihat dari Standar Penilaian Pendidikan secara keseluruhan adalah $86,67 \%$ yang memiliki kategori "sangat baik". Hal ini berarti pencapaian indikator terkait strategi pengembangan penilaian hasil belajar dan portofolio siswa bagi anak berkebutuhan khusus dikategorikan "sangat baik".

Sekolah ini berarti telah melaksanakan pengembangan penilaian hasil belajar dan portofolio bagi anak berkebutuhan khusus dengan "sangat baik".

Berdasarkan keterangan tersebut, secara jelas bahwa persentase ketercapaian Implementasi Manajemen Pendidikan Inklusif di SD Negeri Gadingan dominan lebih besar dibanding MI Ma'arif Pagerharjo untuk semua komponen indikator Standar Pelayanan Minimum (SPM). Hal ini disebabkan oleh berbagai macam alasan dan kondisi yang dimiliki oleh kedua sekolah tersebut, antara lain sebagai berikut.

Pertama, komponen standar pendidik dan tenaga kependidikan, yaitu adanya perbedaan dalam usaha peningkatan dan pengembangan wawasan dan pengetahuan melalui pelatihan-pelatihan. Pendidik dan Tenaga Kependidikan di SD Negeri Gadingan Kecamatan Wates lebih efektif dalam pelaksanaan usaha tersebut, sedangkan di MI Ma'arif Pagerharjo Kecamatan Samigaluh masih kurang (kategori cukup), dimana belum semua guru telah melaku- 
kan usaha peningkatan dan pengembangan wawasan dan pengetahuan melalui pelatihan-pelatihan, termasuk melakukan diseminasi hasil kepada pendidik dan tenaga kependidikan lainnya di sekolah.

Kedua, komponen standar sarana dan prasarana, yaitu macam dan banyaknya fasilitas yang dimiliki berbeda. Di SD Negeri Gadingan Kecamatan Wates memiliki sarana dan prasarana yang lebih banyak dan lengkap, sehingga dalam pengelolaannya lebih serius dan maksimal. Dan di MI Ma'arif Pagerharjo Kecamatan Samigaluh lebih minim adanya sarana dan prasarana tersebut. Hal itu disebabkan bahwa 2 sekolah ini berbeda dalam hal bantuan yang diterima, baik dari pemerintah maupun pemerintah daerah. SD Negeri Gadingan Kecamatan Wates lebih banyak menerima bantuan yang diterima mengingat banyaknya siswa yang berkategori anak berkebutuhan khusus, sehingga perlu penanganan lebih banyak macam dan khusus. Sedangkan di MI Ma'arif Pagerharjo Kecamatan Samigaluh lebih sedikit dalam hal jumlah siswa yang berkebutuhan khusus, sehingga bantuan yang diberikan berbeda.

Ketiga, komponen standar pembiayaan, yaitu dimana 2 sekolah ini memiliki besar anggaran sekolah yang berbeda (dapat dilihat dari jumlah siswa berkebutuhan khusus yang mendapat bantuan). Di SD Negeri Gadingan Kecamatan Wates lebih konsisten dalam menerima bantuan operasional, yaitu hampir setiap tahun dari tahun 2007 hingga tahun 2013. Sedangkan MI Ma'arif Pagerharjo belum pernah sekalipun menerima bantuan operasional untuk peningkatan mutu sekolah inklusi, sehingga hal ini berdampak pada sistem pengelolaan anggaran atau pembiayaan.

Hambatan-hambatan dalam Implementasi Manajemen Pendidikan Inklusif di SD Negeri Gadingan Kecamatan Wates dan di MI Ma'arif Pagerharjo Kecamatan Samigaluh, antara lain: (1) kurangnya kompetensi guru dan kepala sekolah; (2) belum adanya aturan/petunjuk teknis; (3) masih terbatasnya anggaran; (4) bantuan dari Guru Pembimbing Khusus (GPK) masih mi- nim; (5) belum semua orang tua/wali memahami tentang pendidikan inklusif; (6) arakteristik anak berkebutuhan khusus yang sangat variatif;dan (7) minimnya sarana dan prasarana dalam melayani anak berkebutuhan khusus.

Solusi untuk menyelesaikan hambatan-hambatan dalam Implementasi Manajemen Pendidikan Inklusif di SD Negeri Gadingan Kecamatan Wates dan di MI Ma'arif Pagerharjo Kecamatan Samigaluh, antara lain: (1) mengikutkan guru dan kepala sekolah dalam pendidikan dan latihan; (2) menyusun petunjuk teknis yang baku; (3) mengalokasikan anggaran; (4) melakukan konsultasi yang intensif dengan GPK dan guru lainnya; (5) melakukan sosialisasi tentang pendidikan inklusif secara berkala; (6) adanya waktu tambahan dalam melayani anak berkebutuhan khusus; (7) bekerja sama dengan pihak terkait dalam pengadaan sarana dan prasarana.

Rekomendasi Hasil Penelitian adalah sebagai berikut: (1) sekolah sebagai penyelenggara pendidikan inklusif diharapkan dapat meningkatkan, mengembangkan wawasan, dan pengetahuan pendidik dan tenaga kependidikan; (2) sekolah sebagai penyelenggara pendidikan inklusif diharapkan dapat mengoptimalisasi pemenuhan dan pengelolaan sarana dan prasarana; (3) sekolah sebagai penyelenggara pendidikan inklusif diharapkan dapat memenuhi kebutuhan anggaran/pembiayaan pengembangan program pendidikan inklusif.

\section{Simpulan dan Saran}

\section{Simpulan}

Implementasi Manajemen Pendidikan Inklusif dilihat dari Standar Isi di SD Negeri Gadingan Kecamatan Wates telah mencapai skor 138 (93,88\%) dengan kategori "sangat baik" dan di MI Ma'arif Pagerharjo Kecamatan Samigaluh telah mencapai skor 115 (82,14\%) dengan kategori "sangat baik".

Implementasi Manajemen Pendidikan Inklusif dilihat dari Standar Proses di SD Negeri Gadingan Kecamatan Wates mencapai skor 224 (96,97\%) dengan kate- 
gori "sangat baik" dan di MI Ma'arif Pagerharjo Kecamatan Samigaluh telah mencapai skor $177(80,45 \%)$ dengan kategori "sangat baik".

Implementasi Manajemen Pendidikan Inklusif dilihat dari Standar Kompetensi Lulusan di SD Negeri Gadingan Kecamatan Wates mencapai skor $52(82,54 \%)$ dengan kategori "sangat baik" dan di MI Ma'arif Pagerharjo Kecamatan Samigaluh telah mencapai skor 42 (70\%) dengan kategori "baik".

Implementasi Manajemen Pendidikan Inklusif dilihat dari Standar Pendidik dan Tenaga Kependidikan di SD Negeri Gadingan Kecamatan Wates telah mencapai skor 101 (96,19\%) dengan kategori "sangat baik" dan di MI Ma'arif Pagerharjo Kecamatan Samigaluh telah mencapai skor 59 (59\%) dengan kategori "cukup".

Implementasi Manajemen Pendidikan Inklusif dilihat dari Standar Sarana dan Prasarana di SD Negeri Gadingan Kecamatan Wates telah mencapai skor 43 $(68,25 \%)$ dengan kategori "baik" dan di MI Ma'arif Pagerharjo Kecamatan Samigaluh telah mencapai skor 24 (40\%) dengan kategori "cukup".

Implementasi Manajemen Pendidikan Inklusif dilihat dari Standar Pengelolaan di SD Negeri Gadingan Kecamatan Wates mencapai skor 260 (77,38\%) dengan kategori "baik" dan di MI Ma'arif Pagerharjo Kecamatan Samigaluh telah mencapai skor $273(85,31 \%)$ dengan kategori "sangat baik".

Implementasi Manajemen Pendidikan Inklusif dilihat dari Standar Pembiayaan di SD Negeri Gadingan Kecamatan Wates mencapai skor $60(95,24 \%)$ dengan kategori "sangat baik" dan di MI Ma'arif Pagerharjo Kecamatan Samigaluh telah mencapai skor 18 (30\%) dengan kategori "kurang".

Implementasi Manajemen Pendidikan Inklusif dilihat dari Standar Penilaian Pendidikan di SD Negeri Gadingan Kecamatan Wates telah mencapai skor 124 $(98,41 \%)$ dengan kategori "sangat baik" dan di MI Ma'arif Pagerharjo Kecamatan Samigaluh telah mencapai skor 104 $(86,67 \%)$ dengan kategori "sangat baik".
Perbedaan Implementasi Manajemen Pendidikan Inklusif berdasarkan persentase ketercapaian, bahwa Manajemen Pendidikan Inklusif di SD Negeri Gadingan lebih besar dibanding MI Ma'arif Pagerharjo untuk semua komponen indikator standar pelayanan minimum, antara lain terdiri dari: komponen standar pendidik dan tenaga kependidikan, komponen standar sarana dan prasarana, serta komponen standar pembiayaan.

Hambatan-hambatan dalam Implementasi Manajemen Pendidikan Inklusif di SD Negeri Gadingan Kecamatan Wates dan di MI Ma'arif Pagerharjo Kecamatan Samigaluh, antara lain: kurangnya kompetensi guru dan kepala sekolah, belum adanya aturan/petunjuk teknis, masih terbatasnya anggaran, bantuan dari Guru Pembimbing Khusus (GPK) masih minim, belum semua orang tua/wali memahami tentang pendidikan inklusif, karakteristik anak berkebutuhan khusus yang sangat variatif, serta minimnya sarana dan prasarana dalam melayani anak berkebutuhan khusus.

Solusi menyelesaikan Hambatanhambatan dalam Implementasi Manajemen Pendidikan Inklusif di SD Negeri Gadingan Kecamatan Wates dan di MI Ma'arif Pagerharjo Kecamatan Samigaluh, antara lain: mengikutkan guru dan kepala sekolah dalam pendidikan dan latihan, menyusun petunjuk teknis yang baku, mengalokasikan anggaran, melakukan konsultasi yang intensif dengan GPK dan guru lainnya, melakukan sosialisasi tentang pendidikan inklusif secara berkala, adanya waktu tambahan dalam melayani anak berkebutuhan khusus, serta bekerjasama dengan pihak terkait dalam pengadaan sarana dan prasarana.

Rekomendasi hasil penelitian antara lain: sekolah sebagai penyelenggara pendidikan inklusif diharapkan dapat meningkatkan, mengembangkan wawasan, dan pengetahuan pendidik dan tenaga kependidikan, sekolah sebagai penyelenggara pendidikan inklusif diharapkan dapat mengoptimalisasi pemenuhan dan pengelolaan sarana dan prasarana, serta sekolah sebagai penyelenggara pendidikan inklusif diha- 
rapkan dapat memenuhi kebutuhan anggaran/pembiayaan pengembangan program pendidikan inklusif.

Saran

Pemerintah diharapkan dapat menerbitkan petunjuk teknis terkait kebijakan yang telah disusun. Hal ini dapat berhubungan dengan teknis memodifikasi kurikulum, strategi pembelajaran yang menyenangkan, penilaian hasil belajar, serta proses identifikasi dan assemen anak berkebutuhan khusus, sehingga sekolah sebagai bagian dari lembaga dapat mudah dan tepat dalam menerapkan dan melaksanakan kebijakan-kebijakan tersebut.

Dalam mengembangkan program pendidikan inklusif, sekolah atau satuan pendidikan diharapkan memiliki peran efektif dengan pihak-pihak terkait, yakni pemerintah, pihak sekolah, komite sekolah, tokoh masyarakat, orang tua/wali, serta lembaga swadaya masyarakat lainnya. Peran efektif tersebut antara lain terkait dengan kerjasama dari semua pihak dalam memberikan saran dan masukan, pemenuhan sarana dan prasarana, pemenuhan anggaran operasional, melakukan pengawasan, sehingga program pendidikan inklusif dapat berjalan secara bermutu.

Kepala sekolah dan guru diharapkan dapat mengembangkan diri dengan selalu meningkatkan kompetensi profesionalnya. Hal ini dapat diwujudkan melalui pelatihan atau bimbingan teknis, konsultasi dengan pihak-pihak terkait yang mendukung, serta melakukan evaluasi diri, sehingga mampu bersaing dengan semua tantangan dan hambatan yang datang.Saran dapat berupa masukan bagi peneliti berikutnya, dapat pula rekomendasi implikatif dari temuan penelitian.

\section{Daftar Pustaka}

Arikunto, S. (2010). Manajemen penelitian. Jakarta: Rineka Cipta.

Atta, M.A., Shah, M. \& Khan, M.M. (2005). Inclusive school and inclusive teacher. Journal The Dialogue, Volume IV, Number 2, 272-284.
Fattah, N. (2011). Landasan manajemen pendidikan. Bandung: PT. Remaja Rosdakarya.

Hornby, Garry. (2012). Inclusive education for children with special educational needs: a critique of policy and practice in new zealand. Journal of International and Comparative Education, Volume 1, Issue 1, 52-60.

Ilahi, M.T. (2013). Pendidikan inklusif: Konsep dan aplikasi. Yogyakarta: Ar-Ruzz Media.

Menteri Pendidikan Nasional. (2009). Peraturan Menteri Pendidikan Nasional Nomor 70, Tahun 2009, tentang Pendidikan Inklusif bagi Peserta Didik yang Memiliki Kelainan dan Memiliki Potensi Kecerdasan dan/atau Bakat istimewa.

Menteri Pendidikan Nasional. (2010). Peraturan Menteri Pendidikan Nasional Nomor 48, Tahun 2010, tentang Rencana Strategis Pembangunan Pendidikan Nasional Tahun 2010 - 2014.

Minister of National Education. (2010). The indonesian basic education: Road to education for all. Jakarta: Ministry of National Education.

Republik Indonesia. (2003). Undang-undang Republik Indonesia Nomor 20, Tahun 2003, tentang Sistem Pendidikan Nasional.

Sukardjo \& Sari, L.P. (2009). Buku pegangan kuliah: Penilaian dan evaluasi hasil pembelajaran IPA. Yogyakarta: Jurusan Pendidikan IPA FMIPA UNY.

Suyanto \& Mudjito A.K., (2012). Masa depan pendidikan inklusif. Jakarta: Kementerian Pendidikan dan Kebudayaan RI

Tarmansyah. (2007). Inklusi: Pendidikan untuk semua. Jakarta: Depdiknas.

Tilaar, H.A.R. (2006). Standarisasi pendidikan nasional: Suatu tinjauan kritis. Jakarta: Rineka Cipta.

Tim ASB. (2011). Panduan 1: Kriteria standar pelayanan minimum sekolah inklusi. Yogyakarta: Dinas DIKPORA Provinsi DIY dan ASB Indonesia.

Wirawan. (2011). Evaluasi: Teori, model, standar, aplikasi dan profesi. Jakarta: PT. Rajagrafindo Persada. 